\title{
TITLE:
}

\section{Crystal Structure of Triclinic Form of n-Octadecane(Abstract_要旨)}

$\operatorname{AUTHOR}(S)$ :

Hayashida, Toshiaki

CITATION:

Hayashida, Toshiaki. Crystal Structure of Triclinic Form of n-

Octadecane. 京都大学, 1962, 理学博士

ISSUE DATE:

1962-03-23

URL:

http://hdl.handle.net/2433/210877

RIGHT: 


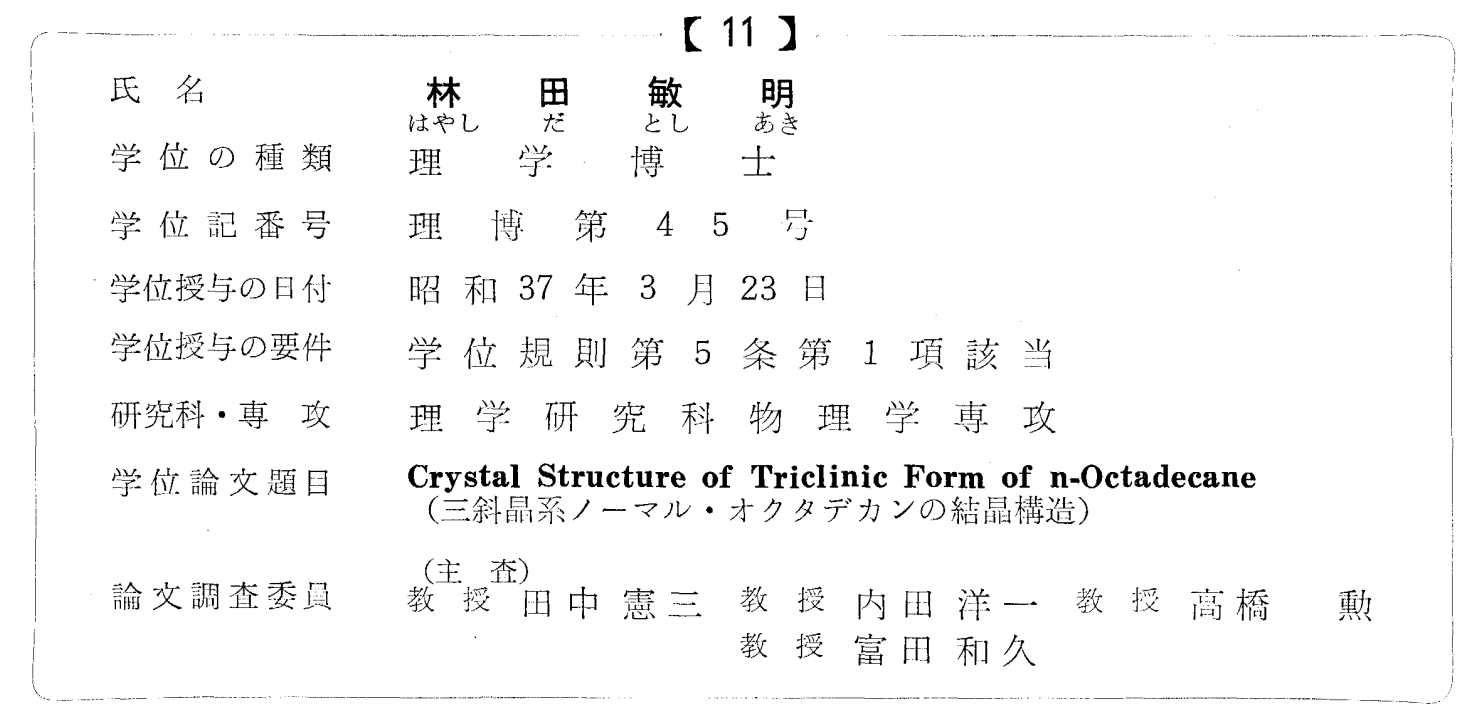

\section{論交内容の要旨}

長鎖化合物のいくつかはその結晶棈造が決定されていて，その小単位胞は斜方，六方，交叉鎖抢よび三斜

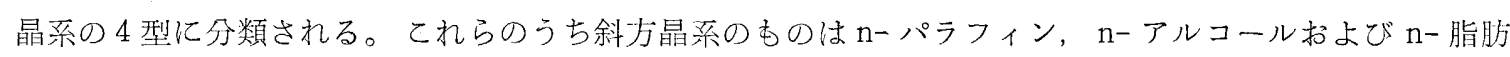
酸の低温相にみられ，それらの構造は精密に決定されている。その他のものについては結晶内の分子の清 め方は未だ決定されていない。三斜型の屯のはまれに見いだされるだけで， müller と Lonosdale クタデカンについてての型を見いだし，その格子常数を決定したがその内部の分子の位䐈は決定していな い。著者はこの物質のての型についてX線的にその構造解析を精密に抢こなって分子の位置を決定した。

この実験に用いた試料はnーオクタデカンのキシレン飽和溶液から析出した結鼠双鼠を含まない部分 を切り出したものである。解析はワイセンベルグ・カメラ在用いて回折写真菜撮影し，その約40個の明膫 な斑点についてミクロフォトメーターによってブラッグ角を精密に测定し，それらの指数と面間隔を決定 した。他方半径 $20 \mathrm{~cm}$ のカメラを用いて (0.01) 反射を記録し長間隔を $23.055 \AA$ と測定した。てれらの 值から最小自乘法で計算した格子常数は次のでとくであった。

$$
\mathrm{a}=4316 \AA, \quad \mathrm{b}=4.893 \AA, \quad \mathrm{c}=25.04 \AA \quad \alpha=83^{\circ} 06^{\prime}, \quad \beta=67^{\circ} 04^{\prime}, \quad \gamma=111^{\circ} 24^{\prime}
$$

この単位胞は 1 個の分子を含むもので，とれらの常数值は前記 Müller と Lonsdale の得た值とよく一 致した。

なお，棈造決定に必要な回折斑点の強度測定は多重フィルム法のワイセンベルグ写真によっておてなわ れた。乙れにローレンッ因子と偏光因子を用いて構造因子を求めた。解析はパターソン法とフーリェ法に よっておこなわれ温度因子の補正も加えて逐次構造の近似を高め, 最後に構造のフーリ工投影図を描いた。 決定された空間群は $\mathrm{C}_{i}^{1}-\mathrm{P} \overline{1}$ で，分子鎖については C-C が $1.54 \AA$, 結合角は $114^{\circ}, \mathrm{C}-\mathrm{H}$ は $1.06 \AA$ で $\mathrm{H}-\mathrm{C}-\mathrm{H}$ の結合角は104゚であった。

この解析の結果知られた特徵は，分子軸方向の温度因子は各原子についてほとんど一定であるととと分 
子軸に垂直な方向では原子の位㯰が分子鎖の雨端に近いほど温度因子が大きくなっていることである。こ のことに関連して従来得られている長鎖化合物結晶のフーリェ投影図をみると電子密度の分布は分子の川 心部付近より屯両端において散漫になっているととである。そこで著者はその原因について検討を加えた。 その一つは構造因子の決定に関して問題になる二重反射, 消衰効果, 強度測定法およびフーリェ級数の打 ち切り等の影響について吟味し，いずれもその原因とはなり得ないとした。他の原因として著者は分了の 熱振動と不純物の影響を検討した。乙れには分子中の各原子がその平衡位置の周りに変動するあのとし, 熱振動のように時間的に変化するものと結晶の不完全さによる時間に無関係なものとを考えた。前者によ るものとしてはとの結晶の分子の詰め方が比較的疎であるから分子軸の周りの分子の捩れが相当起とり得 ると考え, 後者によるあのとしては用いた試料中に不純物として分子の長さの異なるあのが少量であ含ま れている場合はフーリェ投影図の電子密度分布が熱振動の効果と同様分子の両端において散漫になるとと が期待されるとしている。

\section{論 交審查の結果の要旨}

有機物の結晶棈造をX線回折法によって解析することは, 一般に一分子内に含まれる原子の数の多いこ と, 原子のX線散乱能の弱いとと, 試料として用いる単結晶の作製の困難なととなどの理由によって容易 ではない。しかし，長鎖化合物についてもそのいくつかは構造が決定されている。著者が収り上げたのは n-オクタデカンで, その三斜晶系型のものである。てれについては既に Müller と Lonsdale はその格子 常数をX線的に求めているが内部の構造は未定であった。著者はての構造解折を精密におてなって分子の 配型存決定した。

この実験に用いた試料はnーオクタデカンのキシレン飽和溶液から析出したもので双晶を含まない完全な 部分である。解析はワイセンベルグ・カメラを用いて回折写真を撮影し，その約40個の明膫な斑点につい てミクロフォトメーターによってブラッグ角を精密に測定し，そ机らの指数と面間隔を決定した。他方半 径 $20 \mathrm{~cm}$ のカメラを用いて (0.01) 反射を記録し長間隔を $23.055 \AA$ と測定した。乙れらの值から最小自乘 法で計算した格子常数の值は前記 2 氏の結果とよく一致した。

なお，構造決定に必要な回折斑点の強度は多重フィルム法のワイセンベルグ写基によって測定された。 解析はパターソン法とフーリェ法を併用し種々の補正を加えて逐次構造の近似を高め, 鼠後に棈造を示す フーリェ投影図を描いた。求められた空間群は $\mathrm{C}_{1}^{1}-\mathrm{P} 1$ で各原子の位置を示す座俩も決定された。この解 析の結果知られた特徵は, 分子軸方向の温度因子は各原子についてほとんど一定であることと分子軸に垂 直な方向では原子の位置が分子鎖の両端に近いほど温度因子が大きくなっているととである。このととに 関連して従来得られている長鎖化合物結晶のフーリェ投影図をみると電子密度の分布は分子の中心付近よ りも両端に执いて散漫になっているととである。著者はその原因について検傠を加え, 構造因子決定の際 の二重反射, 消衰效果, 強度の実測精度およびフーリェ級数の打ち切り等の影響について吟味し, それら はいずれもその原因とはなり得ないとした。他の原因として著者は分子の熱振動と不純物の影響を考え た。前者によるものとしてはこの結晶の分子の詰め方は比較的疎であるから分子軸の周りの分子の捩れも 相当起とり得るとし，後者に上るあのとしては試料中に不純物として分子の長さの異なるあのが少量でむ 含まれている場合は熱振動と同㥞の効果が期待されるとしている。 
これを要するに, 著者林田敏明は一般には困難な有機物結晶構造の解析において単なる解析にとどまら ず長鎖化合物基通の問題に検討を加え，この分野の研究発展に貢献したところ大であると認められる。 よって，本論文は理学博士の学位論文として洒値あるものと認める。 